\title{
FROM THE INTERCULTURAL COMMUNICATION BARRIERS TO THE INTERCULTURAL ADAPTATION: INTERCULTURAL COMMUNICATION EXPERIENCES
}

\author{
Aysen Temel Eginli \\ Assoc. Prof. Dr., Ege University, Faculty of Communication, TURKEY, \\ aysen.temel.eginli@ege.du.tr.
}

\begin{abstract}
Culture is one of the key factors of a person's perception and interpretation of his/her surrounding environment. All values, norms, meanings and symbols of a society are put across through culture. Thus, culture remains at the core of interpersonal communication. Culture is closely related to an individual's way of establishing and maintaining communication. Information related to culture are very important for communication to become meaningful. Within this context, it is quite possible that the individuals may run into stone walls in interpersonal communication due to the fact that they are not aware of the culture-specific elements. From initiating an interpersonal communication to the way of giving a meaning to verbal and nonverbal expressions, intercultural differences have many positive/negative effects on communication. While the international students enter into a different culture in that country, they also spend time with other students from all around the world in their classes / faculties. This requires adaptation to different cultures, in other words, intercultural learning. Otherwise, this inevitably leads to various problems regarding communication. From this viewpoint, this study aims to examine the intercultural communication problems and the intercultural communication experiences of international students in the process of intercultural adaptation. For this purpose, thematic analysis method is utilized through in-depth interviews with international students, who come from different countries to study in Turkey.
\end{abstract}

Keywords: intercultural communication, intercultural adaptation, international communication experiences.

\section{INTRODUCTION}

The students studying in different countries and student exchange programs began to draw attention with globalization. At this point, intercultural contact has gained significance. It is quite possible that a person may have some communication problems when he/she communicate with somebody from other culture and especially when he/she starts living in another culture.

Communication occurs by verbal and nonverbal code exchange in interpersonal relations. During the communication process, what a person intends to express and how the receiver interprets the message 
completely depend on the culture. It is possible for two people from different cultures to understand each other when they communicate on the basis of grammar and lexical meaning, however, without a cultural context, misunderstandings and communication deficiencies can occur. In this sense, it is of great importance that students who study in a different country should learn intercultural communication idioms and gain intercultural competence during the period between culture shock and intercultural adaptation

\section{THE RELATIONSHIP BETWEEN INTERCULTURAL COMMUNICATION AND INTERCULTURAL ADAPTION}

Bennett (1993) draws attention to the fact that culture develops a new understanding for people to perceive the world around them and in this sense, this understanding differs from culture to culture. In this sense, intercultural adaptation has great significance in developing an intercultural communication and maintaining it.

Intercultural communication is the communication that occurs on the basis of the different knowledge and experiences of people that is from different cultures or subcultures (Kim, 2005). A person who communicates with a different culture or people from different cultures may have adaptation problems due to the given differences and changes at the beginning of the process. Culture shock is having anxiety and stress as a result of losing the familiar symbols and signals of daily life (words, facial expressions, gestures, norms, clothes etc.). Culture shock is completely related to cultural distance and social differences that a person face in the host country. Culture shock results from person's cognitive and behavioural uncertainty and he/she adapts to the culture as his/her intercultural learning increases and the uncertainty is reduced (Gudykunst and Hammer, 1987). In this sense, intercultural adaptation occurs by reduction of the uncertainty that a person feels and developing an understanding of the new culture as a result of living in that culture and having social interactions (Halsberger, 2005). It can be stated that when a person gains cultural adaptation, he/she also improves his/her cultural communicative competency.

Intercultural communicative competency (sometimes it is labelled cross-cultural competency) implies the development of integrated competency related to proficiency in host country's language, cultural awareness, knowledge, attitudes and skills. In this regard, it has been stated that it is possible to improve intercultural communication competency by gaining discourse, linguistics, pragmatic, strategic competency (Usó-Juan and Martínez, 2008). Intercultural communication competency is recognized due to accomplishment of intercultural sensitivity, intercultural awareness, intercultural adroitness stages. Intercultural sensitivity is to be able to experience by approaching a culture and its values open-mindedly; intercultural awareness is approaching intercultural experiences positively and understanding cognitive / emotional clues and intercultural adroitness is having self-disclosure, social and social skills regarding the culture (Kim, 2004).

It is quite natural to face some intercultural communication barriers for the people who study or work in another country or for immigrants during adaptation to the host culture process. It is possible to overcome these barriers by having new experiences by living in that culture as well as having information about the given country and culture in advance and joining the cultural adaptation programs.

\section{THE INTERCULTURAL COMMUNICATION EXPERIENCES OF THE INTERNATIONAL STUDENTS}

International student term is used to indicate a student that benefits international mobility or exchange to complete all of or part of his/her education period in another country (on the basis of contracts between universities or institutions). International student term can also be referred as foreign student or mobile foreign student.

\section{(http://www.kalkinma.gov.tr/Lists/Yaynlar/Attachments/647/Uluslararasi_Ogrenci_Raporu_2015.pdf.pdf)}

The research of Malaklolunthu and Selan (2011) on students' language, social, religious, personal and academic adjustments in universities shows that cultural factors affect overall adaptation and the cultural problems have a negative effect on academic success and learning.

International students face two main problems consisting of unfamiliar culture and academic environment when they go to a country for higher education. Students get stressed because of the differences in teaching and learning styles as well as the problems resulted from cultural differences (Habib et.al, 2014). However, compared to the immigrants, international students are more easily adapted to the cultural differences because they are motivated for education. On the other hand, international students are affected psychologically for living and studying in a country other than their own country and have social integration and academic performance problems as a result (Nicolescu and Galalae, 2013). Ward and Kennedy (1993) have stated that in spite of the differences in countries and the cultures, the international students have 
academic, socio-cultural and psychological adjustment problems.

It has been stated that there are two main reasons of students' adaptation problems in adaptation period: Knowledge of foreign language (English) and academic requirements and expectations. Students feel the difficulty of studying in a new country with different cultural components, in a new educational system with student- teacher interaction (Li and Campbell, 2006).

The biggest problem for the international students is language. Students face language problems (speaking, comprehension, writing etc.) because language of education in higher education institutions is English ( Some countries use their native language as language of education). Most of the students face expression and understanding problems because English is not their native language even though they can speak English (Malakloluntu and Selan, 2011, p. 884).

It has been indicated that international students receive less support and sympathy from domestic students because of their language problems and as a result they suffer from anxiety, stress and isolation. Besides, the students have stated that their social and emotional needs are not completely understood and not provided as a result (Andrade, 2006).

$\mathrm{Li}$ and Campbell (2006) have stated in their research, "A Case Study of Asian Students' Learning Experiences at a New Zealand University" that Asian students liked the interactive learning process and were very pleased to be included in the learning process by the lecturers. Besides, students have stated that they had faced language difficulties and cultural differencing as intercultural communication barriers. They have stated that they had difficulties especially in unfamiliar patterns of classroom interactions not knowing academic norms and insufficient support during learning process.

Bamford (2008) has stated in the research International Students' Academic and Cultural Experiences of Studying in the UK conducted in London Metropolitan University Business School that students point out that the university provided convenience in friendship and social network and that affected their adaptation positively. She has also stated that students explain that they feel more self-conscious in another culture and the lecturers should understand their non-verbal communication and consider cultural differences.

Lin (2012) indicates in her research "Students of Different Minds: Bridging the Gaps of International Students Studying in the US" that international students express their problem as homesickness and loneliness in the social life. Besides, they have stated American people are open, polite and have high intercultural awareness.

Hellstén and Prescott (2004) have pointed out that students highlight the positive features of being in a different country in their research regarding the experiences of international students in Australia. In this sense, students have stated that the Australians have intercultural awareness and cultural open-mindedness and are away from stereotypical thinking and they learn better with inclusive teaching system.

It has been indicated that the students studying in a foreign country have individual economic and cultural costs. So the international students face emotional and social loneliness. Sawir et.al. (2008) have stated that they face cultural loneliness as well as social and emotional loneliness. The main reasons of feeling lonely are stated as individualistic or collectivist culture features, not having a good understanding of the language, not being able to communicate, personal characteristics, and operation and education system of the university.

\section{AN ANALYSIS OF INTERCULTURAL COMMUNICATION EXPERIENCES OF THE STUDENTS IN THE PROCESS OF GETTING TO KNOW A CULTURE AND ADAPTATION}

The aim of the research is to determine the intercultural communication barriers and experiences of international students during the adaptation to a different culture. In this context, we seek answers for two research questions.

R Q1:Ç What are the intercultural communication problems/barriers that international students when they get education in a new culture?

R Q2: What are the intercultural communication experiences of international students that they acquire during their education in a new culture?

The sample of the research are decided through the method called "Simple Random Sampling" that came to light by the students who came to Ege University (Turkey) with the student exchange programs such as Socrates Erasmus and Foreign Student Admittance. The sample of the research consist of 4 female and 2 
male students that came from Russia, Azerbaijan, Tatary, Greece, Lithuania and Poland. The students are both undergraduate and graduate students whose ages range from 21 to 26 .

\begin{tabular}{|l|l|l|l|l|}
\hline Student name & Age & Education & Country & Gender \\
\hline Linar & 25 & Graduate & Russia & Boy \\
\hline Kahmal & 26 & Graduate & Azerbaijan & Boy \\
\hline Galia & 24 & Graduate & Tatary & Girl \\
\hline Angeliki & 24 & Undergraduate & Greece & Girl \\
\hline Olessia & 21 & Undergraduate & Lithuania & Girl \\
\hline Simona & 22 & Undergraduate & Poland & Girl \\
\hline
\end{tabular}

Table 1: The demographic data of the informants

The obtained data through face to face in-depth interviews with the international students are evaluated with thematic analysis method. Thematic analysis is a qualitative evaluation method. "Thematic analysis is a method for identifying, analysing, and reporting patterns (themes) within data. It minimally organizes and describes your data set in (rich) detail (Braun and Clarke, 2006)". In-depth interview pre-set range of questions about research topic which was performed in accordance with the answers of each participant. The obtained data after the interview were grouped into themes with deductive coding method. Then, themes were categorized into sub-categories.

\subsection{Research Findings}

6 themes are formed after the categorization of the data obtained from the research; previous intercultural experiences, living abroad, learning about country, intercultural learning, feelings, intercultural communication problems/barriers. The participant's answers, interpretations and feedback of each theme are evaluated with theoretical frame.

\subsubsection{Previous intercultural experiences (about other countries or Turkey)}

When it is assessed if the international students have been to another countries or Turkey and have had a cultural experience, two of the students have stated that they visited Turkey but didn't have information regarding culture because they were short visits; on the other hand they had prejudices. Two of the students have been to different countries for education and the can state that they are able to assess cultural experiences. In this sense, they can state that they have never experienced culture shock; they came here knowing that cultural differences might occur and they are ready for them because they want to get to know the culture.

"I have been to London for my high school education before. England's culture was closer to mine. Turkey is much more different. But I wasn't shocked at all."

"I have been to Greece for education; their education system was too different compared to mine. Most of their cultural features resemble Turkey's."

"I have been to Turkey, Antalya as a tourist. Turkey had always been a touristic place on my mind. I perceive it as a touristic place. But my opinions changed." I felt strange at the beginning but I didn't experience culture shock."

"I had prejudices about Turkey. My friend had been to here. Izmir is so different, a person should experience it in his own I think. My opinions changed when I see it.

\subsubsection{Learning about Turkey and Turkish People}

When we assess the students' experiences and statements regarding Turkey, we see that they identify Turkish People with positive adjectives like hospitable, sympathetic and friendly, and although their perception of Turkey includes some negativity, they assess it as interesting rather than negative knowing that there are differences in values, norms and daily life practices. International students have stated that they will recommend their friends to go to Turkey when they go back to their home countries due to their positive experiences with Turkey and Turkish people.

"There are "Gold Bazaars" everywhere. At first, I thought the economy is really good. Then I thought it is important to sell gold." 
"That picture comes to my mind when they say Turkey. Rug, nargile, leather shops, upbeat music."

"They are very helpful. The first day I was in Izmir and Turkey, I was heading to the dormitory and I didn't prefer taking a taxi because I didn't know the distance. While I was trying to walk with lots of suitcases in my hands, a woman approached and asked if I needed help. I said "No.". After a short while, someone else asked if I needed help and helped me to carry my suitcases to the dormitory. Actually I was very surprised."

"Turkish people are really hospitable. Turkish cuisine is so delicious but Turkish people are too insistent. They go on insisting even though you say you don't want it. Even the waiters behave in that way. You drink tea somewhere. They ask if you want the second glass of tea before you finish the first one and sometimes they bring it without asking you!"

"Traffic system is very interesting. In my country all the cars stop at the pedestrian cross while the pedestrians crossing the road but in Turkey the drivers don't stop even at the red lights. So I learned to check the road even the light is on for the pedestrians."

"Izmir differs radically from other cities of Turkey. I have been to Istanbul, either. People are more relaxed and more open-minded."

"Turkish people really love to communicate and are very friendly. But sometimes that leads them to ask questions about private subjects and that disturbs a little."

"Political view is of great significance for them. They can give long speeches on political subjects."

"I observed Turkish people as religious and conservative. But in Izmir there are less religious and conservative people. But I can make it as a general statement."

"They love their leader Atatürk so much. The subway stopped suddenly on November 10 at 09.05 and all the people stood up. Everybody stood in silent homage. I was really surprised and impressed."

\subsubsection{Culture and Values}

It has been understood that the international students didn't experience culture shock and they were aware that they could face cultural differences when their statements are assessed. Despite the awareness of cultural differences, it has been stated that they find them interesting, strange, illogical etc. when they face cultural factors. Their assessments about cultural differences in Turkey are basically divided into three subjects which are perception, habits and social behaviour. It has been observed that international students find daily life practices in Turkey strange and have difficulty in adapting.

"Everybody drinks tea? When they ask you "What would you like to drink?" they mean "Would you like some tea?" You usually feel that you should drink something."

"Turkish coffee tastes really good but people equate coffee with fortune telling. They turn down the coffee cups right after finishing their coffee.

There is a place labeled Küçük Park, you know, most students spends their spare time in the cafes there. They meet their friends, chat, eat and drink something. These are normal activities. What I find strange is I pass by it at 04.00 because I get off the plane at this time and I see people gathering and drinking tea at Küçük Park. That's really interesting. In my opinion what you can do at 04.00 am is to drink alcohol and come back from bar.

"Dolma is important! They say dolma, and it is stuffed pepper with rice and they say sarma and it is stuffed grape leaves with rice. I see no difference between them. But they are so important for food culture."

Visits are important. When you visit a home, everybody there meets you at the door, and they come to the door when they see you off. They even open a new conversation in front of the door and sometimes they wave goodbye from the balcony."

"Time concept and management in Turkish culture is quite different. People say they would be somewhere at a certain time and I go there at that time. They don't. They are usually late. I join an organization and it starts absolutely late. Sometimes they say ten minutes later and I know ten minutes means half an hour."

"Turkish culture is a synthesis, there is a little bit European effect on the behaviours but there is a traditional perception at the same time."

\subsubsection{Feelings}

International students feel lonely because they are apart from their families, friends and their own homes. They have also stated that they feel "out of place" and are perceived as different. On the other hand, 
loneliness and fear can be assessed related to gender, because such feelings have been stated by female students. However, students feeling accepted and hosted can be assessed positively despite their feeling out of place in Turkey.

"I miss my family so much. Sometimes I would like to talk to someone in my native language and at those times I don't feel lonely. We are lucky to have technological opportunities; I see and talk to my family every day."

"Some attitudes toward women are quite interesting. It is enough to be a foreign woman to draw attention. So I got followed a few times and I was quite scared."

"I felt stressed about my clothing. I wore shorts or short skirts in summer season and the eyes rested on me were disturbing.

I wanted to go back to my home country at the beginning. I pictured moving back to Russia on my mind but I told to myself "What are you going to do there? You are here for your education."when I thought logically."

"I never felt lonely on the campus but .I usually felt lonely off the campus."

"You feel lonely. You don't have a family, friends. But what is interesting about it is that you get on the bus, you don't know the people but you recognize the facial expressions, you can't even read them in this situation. What makes you feel lonely is that!"

"I felt accepted in this country, even in this faculty. Most of the time people hold my hand and took me where I wished to go. People drop everything and take care of you. That feels good. Sometimes being a stranger in this country is a good thing."

\subsubsection{Problems / Barriers}

Considering barriers and problems about communication that participants encounter, it has been observed that there are three essential points in regarding this situation. First of all, expressions in Turkish culture are more indirect and that most of the time these indirect expressions lead misunderstandings. Second, culture has an effect on daily procedures It has been observed that international students may have problems about accommodation and the university and they are unable to solve these problems. The third one can be considered as English as a language factor. Most of the international students have to speak English in their daily lives and having lack of English speakers on or off the campus can be considered as a challenge for them. However, it has been stated that people are willing to help and they give an effort to solve detected problems.

"There are so many bureaucratic procedures. You have to talk to different people to get a job done and it takes several days."

"When you ask a question about a process people in charge say that things just work like this, there is no logical explanation!"

"Even though you don't ask for help people try to help you. They don't know English but still they want to help so they take me to a person who can speak English."

"There are few people who can speak English and I think most of them are not sufficient enough. Nobody knows my native language, I admit, but it is frustrating not being able to express yourself when people can't speak English."

"We have some problems about getting services at the dormitories. For example, there were no food at the dorm for two days; there was something wrong at the cafeteria. I said OK, and then they told us to do our laundry at somewhere else because there was a water shortage. I asked them what about us. I was in shock."

"Sometimes it might take a long time to complete errands. My student certificates got completed a long time after my arrival, I worked a lot on the paperwork. The person in charge said that these things take some time; they are really hard to deal with. I applied a year ago. It is really hard, I thought."

"In Turkish culture expressions are so indirect. Instead of telling the reason of a situation directly, people tell it in the long way."

"Turkish people don't say no. They say 'we'll see' or 'come again later'. You think they will solve the problem but actually they've meant no."

"I had done everything about my paperwork. One day they called me and said something was missing in my 
documents. Nobody explained the reason; they just told me to do things. They can go back to a finished job. That's interesting."

\subsubsection{Education}

As a result of the evaluations that international students made about class management, class rules and the lecturers in academic environment that they are not accustomed to, they stated that they liked the education system, conducted studies, lecturers and their friends' attitudes and university's positive approach towards education in Turkey. Besides, during their education, positive experiences they have with their lecturers and friends make it easy for them to adapt the new culture and prevent them to feel like and outsider.

"Compare to my country, education system in Turkey is more disciplined. If you do as the lecturers say, you become successful."

"In the education system, students are also included in the lectures. In some classes students do projects with the lecturers and I find this very helpful."

"I thought Turkey was an underdeveloped country. I had no idea about the education system and frankly, I was afraid but I saw that their education system is in world class standards. Conducted researches and knowledge of the lecturers are really satisfying."

'Whenever I visit my advisor, she/ he always says 'come in', and offers me coffee. Having and advisor is good for both educational and social life, I feel at home."

"It is really great that lecturers advise students and approach friendly towards the students. This is why I think won't have difficulty in writing my thesis."

"My classmates are really helpful and guiding. I see that $\mathrm{i}$ is really important for thinking the other in terms of friendship."

\section{RESULTS}

As a result of the questions in the study which was conducted to determine intercultural communication barriers and experiences of international students in the process of adapting to a different culture, 6 themes such as previous intercultural experiences, learning about Turkey and Turkish people, culture and values, feelings, education, problems/barriers were formed. It has been determined that problems which are experienced by international students are mostly because of indirect expressions in Turkish language and culture and cultural effects on daily procedures and lacking knowledge of English language in Turkey. An important point about intercultural communication and cross cultural experiences is that international students did not experience culture shock. The reason behind this can be explained by Turkish people being friendly and eager to help. It has been observed that the reason why international students have given positive evaluation on Turkish education system is the relationship between lecturers and students. They have found assigning advisors to all students when they choose their courses or consulting their problems very useful. Besides, it has also been observed that international student's perception of Turkey and Turkish culture has changed positively after they experienced Turkish culture. The most interesting finding of this research is international students adopting Turkish culture easily and managing this process by being prepared for the cultural differences. Students were chosen by using basic random sampling and them being reluctant to participate in this research is considered as the restriction of the research. Thus, the number of the students in this study, which is 6 , can be considered as a restriction. This study can focus on how international students follow a method to adopt cultural differences for further researches will be carried out on cultural experiences or problems of international students in the future.

\section{REFERENCE LIST}

Andrade, M. S. (2006). International students in English-speaking universities: Adjustment factors. Journal of Research in International Education. 5(2).

Bamford,J.( 2008). Strategies for the improvement of international students' academic and cultural experiences of studying in the UK. Hospitality, Leisure, Sport and Tourism Network: Enhancing Series: Internationalisation.York: HEA Academy.

Bennet, J. M. (1993). Towards ethorelativism: a developmental model of intercultural sensitivity, in. (ed.) R. Michael Paige, Education for the Intercultural Experience. Yarmouth: Intercultural Pres.

Bhawuk, D.P.S., Landis, D. \& Lo Kevin, D. (2006). Intercultural Training. In D. L. Sam. nd J. W. Berry (eds), The Cambridge Handbook of Acculturation Psychology. Cambridge:Cambridge University Press. 
Braun, V. \&Clarke, V. (2006). Using thematic analysis in psychology. Qualitative Research in Psychology, 3 (2). pp. 77-101 from Boyatzis, R. E. (1998). Transforming qualitative information: Thematic analysis and code development. Thousand Oaks, CA: Sage.

Gudykunst, W.B., \& Hammer, M.R. (1987). Strangers and hosts: An uncertainty reduction based theory of intercultural adaptation. In Kim, Y.Y. \& Gudykunst, W.B. (Eds.), Cross-cultural adaptation: Current approaches. Newbury Park, CA: Sage Publications.

Habib, L., Johannesen, M., \& Øgrim, L. (2014). Experiences and Challenges of International Students in Technology-Rich Learning Environments. Educational Technology \& Society, 17 (2).

Haslberger, A (2005). Facets and dimensions of cross-cultural adaptation: refining the tools. Personnel Review. Vol. 34 No.1.

KIM, Y. Y. (2005). Inquiry in Intercultural and Development Communica-tion. Journal of Communication, 55 (3).

Kim, R.K. (2004). Intercultural Communication Competence: Initial Application To Instructor's Communication As A Basis To Assess Multicultural Teacher Education Programs, A Thesis Submitted To The Gradution Of The University Of Hawai Master of Arts.

Li,M.\& Campbell,J.(2006). Cultural Adaptation: A Case Study of Asian Students' Learning Experiences at a New Zealand University, Proceedings of the EDU-COM 2006 International Conference. Engagement and Empowerment: New Opportunities for Growth in Higher Education, Edith Cowan University, Perth Western Australia, 22-24 November 2006. http://ro.ecu.edu.au/ceducom/86.

Malaklolunthu, S. \& Selan,P.S.(2011). Adjustment problems among international students in Malaysian private higher education institutions. Procedia Social and Behavioral Sciences.15.

Natarova,T. (2011). Intercultural communication experiences of foreign students with a focus on their perspectives of national, cultural and ethnic identity: Case of Exchange and Degree Students in Jyväskylä, Finland. Master's Thesis, Intercultural Communication Department of Communication University of Jyväskylä.

Nicolescu, L.\& Galalae, C. (2013). A Systematic Literature Review on Students' International Mobility and Cultural Adjustment. Management \& Marketing Challenges for the Knowledge Society. Vol. 8, No. 2.

Oberg, K. (2006). Cultural Shock: Adjustment to Ne Cultural Environments, Practical Anthropology, Curare, 2006, 2+3,142-146 reprint from. Oberg, K.(1960). Cultural Shock: Adjustment to Ne Cultural Environments, Practical Anthropology, 7.

Sawir, E, Marginson,S., Deumert,A., Nyland, C. \& Ramia, G. (2008).Loneliness and International Students: An Australian Study, Journal of Studies in International Education, 12(2).

Usó-Juan,E.\& Martínez, A. (2008). Teaching Intercultural Communicative Competence through the Four Skills, Revista Alicantina de Estudios Ingleses. 21.

Ward, C. \& Kennedy, A. (1993). Where's the culture' in cross-cultural transition? Comparative study of sojourner adjustment, Journal of Cross-cultural Psychology, vol. 24, no. 2.

_._. (2015). Yükseköğretimin Uluslararasılaşması Çerçevesinde Türk Üniversitelerinin Uluslararası Öğrenciler İçin Çekim Merkezi Haline Getirilmesi, Araştırma Projesi Raporu, T.C.Kalkınma Bakanlığı, Kalkınma Araştırmaları Merkezi. http://www.kalkinma.gov.tr/Lists/Yaynlar/Attachments/647/Uluslararasi_Ogrenci_Raporu_2015.pdf.pdf. 